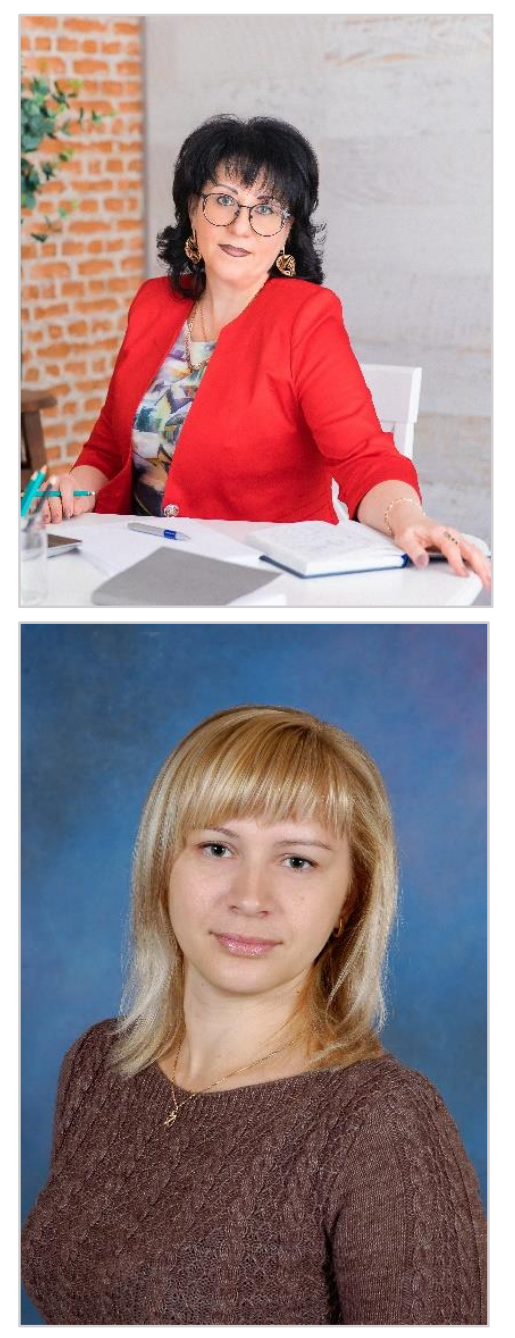

\title{
DIGITAL LEARNING ENVIRONMENT FOR PRIMARY SCHOOL TEACHERS TRAINING
}

\author{
Liudmyla Havrilova \\ Dr. Hab. in Pedagogics, Professor, \\ Head of the Primary Education \\ Theory and Practice Department \\ SHEI "Donbas State Pedagogical University", \\ Sloviansk, Ukraine \\ ORCID ID 0000-0003-1814-5323 \\ havrilovalg@gmail.com \\ Olena Beskorsa \\ Candidate of Pedagogical Sciences, \\ Associate Professor of Primary Education \\ Theory and Practice Department \\ SHEI "Donbas State Pedagogical University", \\ Sloviansk, Ukraine \\ ORCID ID 0000-0001-8018-8549 \\ beskorsyhelen@gmail.com
}

\begin{abstract}
The issue of designing the learning environment, which opens the access to modern educational resources and contributes to developing a new level of interaction between teachers and students, is extremely relevant for national system of higher education. The development of digital technologies makes it possible to design qualitative, hi-tech learning environment for training specialists of different professions. The signing the Association Agreement between Ukraine and EU accelerates the process of digitalizing national education that is proved by a number of legislative initiatives and strategic documents, Digital Agenda of Ukraine - 2020 (2016), Law of Ukraine On Education (2017), Concept "New Ukrainian School", Regulation on Electronic Textbooks, and Regulation on National Educational Electronic Platform are among them.

The purpose of the article is to analyse and generalize national and foreign experience about designing open electronic learning environment that gives an opportunity to model digital learning environment for training primary school teachers, as well as to describe the structure and content of this pedagogical phenomenon. The principles of open education and regulations of competence-based approach constitute the theoretical justification of research. The author analyse the national experience of designing innovative e-environment: the model of electronic educational platform Universal educational environment - ACCENT (http://ac-cent.com/) and electronic platform mobiSchool which are designed by Ukrainian scientists and implemented into the practice as webtools of electronic learning in secondary schools. It is noted that foreign countries have more experience of creating electronic learning resources, including open digital learning tools, courses,
\end{abstract}


and textbooks. Among widespread information and communication environments there are Open Educational Resources (OER, https://www.oercommons.org/), Coursera (http://www.coursera.org), Academic Earth (http://academicearth.org), and online platforms of repositories of educational resources of Harvard and Preston Universities, Massachusetts Technological Institution and others.

It is set out that in foreign pedagogy studies more modern generation of learning resources, Next Generation of Digital Learning Environment (NGDLE). NGDLE is designed as a universal digital learning platform for school teachers and students, university teachers and students, locating and providing software, learning services and tools for learning management. The authors describe the project of digital learning environment for training primary school teachers, designed by the teachers of SHEI "Donbas State Pedagogical University". The educational resource corresponds to the principles of open education and contains the following subsections: digital learning resources, web-conferences, webinars, scientific and methodological repository, methodological portal, distance courses for matriculants, forum and news.

Key words: digital learning environment; open access; open educational resources; e-learning environment; National Educational Electronic Platform; primary school teachers.

Statement of the problem in general. Digitalisation is a dominant trend of developing modern information society that takes place at all the educational stages from pre-school to adult education, in the area of both formal and informal education. The concepts of digital literacy, digital competence, digital pedagogy are entered into the scientific use of Humanitarian areas of education. In recent years, more and more attention is paid to upgrading educational resources, which, as a lot of scientisttheorists and practitioner-teachers think, should be designed by using computer (digital, information and communication) technologies, taking principles of open education into consideration and should be accessible for students due to posting on the Internet. The educators from different countries discuss the problems of designing and functioning specific learning environments that give an access to modern learning resources and contribute to developing a new level of the interaction between teachers and students.

Analysing the latest researches and publications. The importance and relevance of creating the learning environment, which meets the requirements of new information era, including digital transformations, are discussed in the documents of European Commission, strategies and agendas of international organizations, as well as in national and foreign researches of recent years.

Taking into consideration the signing of Association Agreement between Ukraine and EU, the main purposes of developing information society in Ukraine by 2020 begin to correspond to European guidelines of education, including regulations of initiative Digital Agenda for Europe that was adopted within the European strategy of economic development Europe 2020 Strategy for Smart, Sustainable and Inclusive Growth. In this document the improvement of computer (digital) literacy and skills, accessibility of digital services, including educational ones (Digital Agenda for 
Europe, 2010) is claimed to be the priority spheres. Based on the previous document, in 2016 Project "Digital Agenda of Ukraine - 2020" which develops the key guidelines of European strategy of developing the digital society, was designed. Among the changes, being planned in educational sphere, the relevance of developing the digital literacy and digital competence is regarded as key one for fulfilling life and work activities (Digital Agenda of Ukraine, 2016).

National Strategy of education development in Ukraine in 2012 - 2021, Law of Ukraine on Education, and the Concept "New Ukrainian School" tell about the improvement of information support, modernization of the education structure and content on the basis of informatization and digitalisation. According to the new requirements, information and communication competence is included into the conceptual framework of new Ukrainian school as one of the key competences that should become a cutting-edge one in the content of all school subjects (New Ukrainian School, 2017).

In Strategy of Information Society Development in Ukraine, the concept "electronic learning" (e-learning) has been introduced into the list of main forms of education as a form of getting education that is gained by the use of information and communication technologies (Strategy of Information Society Development, 2013).

Documental and legislative base of using electronic learning resources is normalized: Regulation on Electronic Educational Resources was adopted (2012) in which different types of electronic learning editions (textbook, tutorial, web-site etc.) are determined and regarded as modern learning tools; Regulation on Electronic Textbooks (2018) was adopted in which the requirements to the content and structure of this learning tool were designed.

One of the main trends of national e-education includes open electronic learning resources and digital learning tools of different types which, according to the statement of Minister of Education and Science of Ukraine L. Hrynevych, are planned to be located at the unified database which should be designed and adopted for the national education system. In 2008, Ministry of Education and Science of Ukraine approved at the legislative level the launch of the national educational platform that would provide all the participants of education process with the free access to e-textbooks, make the quality of education higher and more accessible for studenti and teachers in rural areas, contribute to significant changes in educational process, allow to establish the market of producing electronic educational products and services, and activate the development of digital competence of educational process participants in Ukraine (Regulation on National Educational Electronic Platform, 2018). 
The national educational platform, built on the principles of open education, should be realized on the basis of the implementation of the Concept "New Ukrainian school" and provide the secondary stage of education with electronic learning tools. Regarding the national higher education, the problem of designing the qualitative digital learning content hasn't been solved yet, even not declared at the state level. The emergence of learning tools of new generation (electronic textbooks and teaching aids, multimedia digital learning resources) is the matter of enthusiasts who think that it is necessary to upgrade learning and methodological support of professional training of specialists in different spheres. One of the examples is digital learning environment of primary school teachers training, designed and partially realized in practice by the lecturers of Primary Education Theory and Practice Department at SHEI "Donbas State Pedagogical University".

We will try to analyse and generalize the national and foreign experience of designing the open electronic learning environment that makes it possible to model the digital educational environment of primary school teacher training, we will also describe the structure and content of this pedagogical phenomenon, that will constitute the purpose of the article.

Theoretical ground of the study. The theoretical basis of studying the issue of designing digital learning environment for providing the qualitative training of primary school teachers constitutes the principles of open education that is determined by OpenEdu Framework for Higher Education Institutions, designed by specialists of European Commission, and is a form of education, based on using digital technologies, aimed at increasing the access to learning, eliminating barriers, creating new methods of teaching and learning, knowledge exchange, and providing different ways of access to formal and informal education (Inamorato dos Santos, Punie \& Castaño-Muñoz, 2016). Ten components of open education, emphasized in this document, are relevant, they are: Access; Open Educational Resources, OER; Opening up Pedagogy, which includes Supported Open Learning, Personalised Teaching, Collaborative and Network Learning, Use of Authentic Resources and Sharing Educational Resources and Pedagogical Practices; Recognition; Open Research; Strategy; Technology; Quality; Collaborative; Leadership.

The projecting of digital educational environment for training future teachers occurs, taking into account the principles of competency-based approach, which is one of the strategic directions of national policy in educational sphere, reformation of education system in Ukraine, modernization of its structure and content. The competency-based approach leads the process of professional training of future specialists in the sphere of education (in this case future primary school teachers) to 
the particular result, namely the development of their professional competence by means of digital technologies and ensures the successful professional realization in the future.

The results of the study. In academic year 2018-2019, at the Faculty of Primary, Technological and Vocational Education at SHEI "Donbas State Pedagogical University" the project "Digital Learning Environment of Primary School Teacher Training" has been modelled and its implementation has stated.

The project is aimed at the active involvement of digital technologies into primary school teacher training for improving its effectiveness, increasing the access to learning resources, and mastering new forms of interaction between lecturers and students.

Designing the digital learning environment started with studying the existing national and foreign experience. It was found out that the attempts to create an innovative e-environment for learning started in 2016.

The team of Ukrainian scientists (N. Bakhmat, L. Kartashova, V. Liubarets and others) suggested the existing model of electronic educational platform - Universal Learning Environment ACCENT (http://ac-cent.com/) - a powerful, open, and innovative e-mechanism for improving the education quality in Ukraine. ACCENT was designed for creating electronic learning environment of the educational institution; constructing electronic prototype of an educational institution with all the necessary components; creating the system of distance learning; establishing and supporting the distance learning; designing electronic learning resources; supporting and consulting educators continuously for improving the level of their IT-competence (Universal Learning Environment, n.d.; Liubarets, 2016).

Learning environment ACCENT was created as the single integrated system that includes: repository of electronic learning resources (ELR) - learning tools in any form (electronic textbooks, teaching aids, information and reference editions, presentations, infographic tools etc.); e-environment of an educational institution for providing the support of functions of managing the educational process; the net of an electronic learning course; tools for creating and supporting social networks for educators, aimed at their communication and organizing the work on group projects (Liubarets, 2016).

Unfortunately, nowadays the site of Universal Learning Environment ACCENT doesn't give an access to the listed on the homepage 10000 electronic learning materials, more than 8500 of electronic learning classrooms and auditoriums, that is the site authors don't follow the proposed principles of open education or learning environment ACCENT doesn't work for certain reasons. 


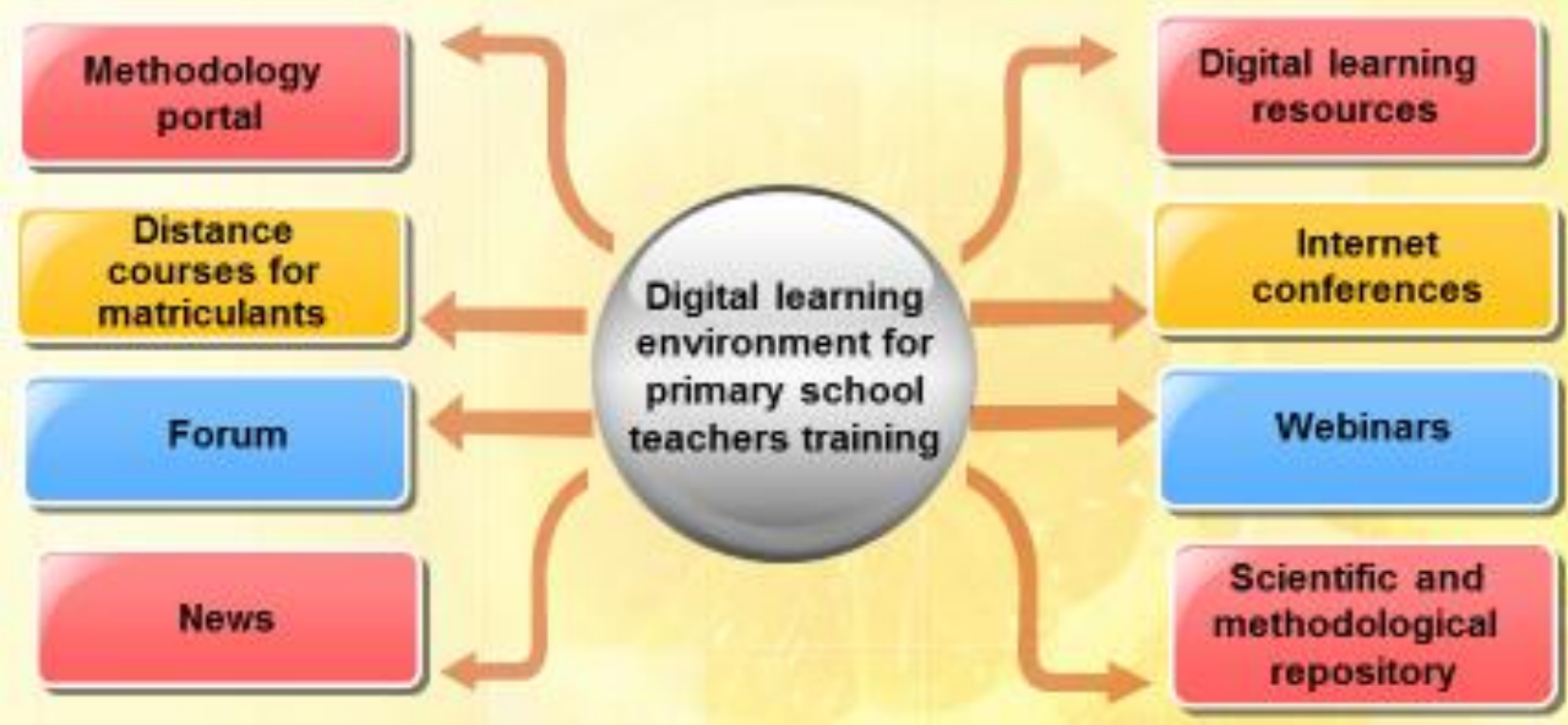

Fig. 1. Model of the digital learning environment for primary school teacher training (SHEI “Donbas State Pedagogical University”)

Ukrainian scientists L. Kartashova, N. Bakhmat, and I. Plish (2018) designed and implemented electronic (web-) platform mobiSchool as web-toolkit that can't be used as a learning database, which creates authentic conditions of learning in any educational institution, provides every participant of educational process with the prospects of gaining and updating knowledge, developing, improving and selfrealizing over a lifetime. The electronic platform mobiSchool was experimentally implemented as a web-prototype of educational complex "School-kindergarten "Lisova kazka" - the grammar school "Apohei" with the name "System of Distance Learning of Grammar School "Apohei” (Kartashova, Bakhmat, \& Plish, 2018). The result of the implementation, as scientists asserted, was the formation of innovative eenvironment as a factor of continuing development of educators' digital competence.

The processes of designing digital learning environments are established more actively in foreign education: for meeting educational needs in different countries a large number of electronic educational resources have been created, including open digital learning tools, courses, and textbooks etc. Among the widespread information and communication environments of open education there are:

1. Open Educational Resources (OER, https://www.oercommons.org/) - webenvironment that gives an access to learning materials (online courses, modules, textbooks, streaming videos, texts), software, other tools, materials and methods, which are used for supporting an access to knowledge in different areas. Moreover, it gives an opportunity to communicate with educators all over the world. 
2. Coursera (http://www.coursera.org) - a platform of free online courses (about 600) with video lecturers, tasks and discussions on forums from lecturers of leading world universities, giving an opportunity to get electronic certificate after completing the course.

3. Academic Earth (http://academicearth.org) - a collection of free online courses in psychology, pedagogy, management and others, designed by specialists of the best world universities.

For the system of higher education, as well as for continuing education and lifelong education a considerable number of online courses are designed (a lot of them are free), an access to repositories of video lecturers and courses of leading world scientists is opened: a large number of open learning resources can be found in international educational network World-lecture-project (http://world-lecture-project.org/), which gives an access to complete courses and video lecturers in different scientific fields from well-known world education institutions; video courses of the best world universities are proposed by MyEducationKey (http://www.myeducationkey.com) the virtual educational portal that gives an open access to learning video lecturers and other multimedia tools for students, pupils and teachers.

The leading world universities have their own online-platforms where repositories of learning resources (scientists' video lecturers, online courses) are located: web-resource edX (https://www.edx.org/), designed by Harvard University and Massachusetts Institute of Technology; media center of Princeton University (https://mediacentral.princeton.edu/); audio and visual leaning resources of Massachusetts Institute of Technology (https://ocw.mit.edu/courses/audio-videocourses/) and others.

The majority of mentioned resources can work successfully on any digital devices (smartphones, iPhones, and tablets), they show in practice the effectiveness of open education, declared in the international documents (The Cape Town Open Education Declaration, 2007, http://www.capetowndeclaration.org/; Analysis and mapping of innovative teaching and learning for all through new Technologies and Open Educational Resources in Europe, 2013, https://eur-lex.europa.eu/legalcontent/EN/TXT/PDF/?uri=CELEX:52013SC0341\&from=EN etc.).

The scientists M. Brown (2017), G. Dobbin (2016), M. Lynch (2018) and others, who work on theoretical and practical support of open education, recently have discussed more modern generation of learning resources which they call the Next Generation of Digital Learning Environment (NGDLE). NGDLE should become a universal digital learning platform for teachers and school students, lecturers and students, place of location and providing software, educational services and tools for 
managing education. The software for new generation of learning resources will contain in one place all the necessary components and realize such functions as submitting materials, testing, managing data, timetable, learning analyst, multimedia, tools for collaboration and communication, tools for changing materials and supporting education. This platform must support learning activities of both lecturers and students.

M. Brown (2017) emphasizes five key functions of digital learning environment of next generation:

1. Interoperability and Integration, data exchange through the platform.

2. Personalization: learning activities for everyone.

3. Analytics, Advising, and Learning Assessment.

4. Collaboration.

5. Accessibility and Universal Design, optimized for the use and access on different devices.

The implementation of the Next Generation of Digital Learning Environment started in 2015 at some universities in the USA. As the scientists assert, NGDLE is thought to be a certain eco-system - learning environment which consists of the learning tools and components that correspond to the general standards. Moreover, this environment to a larger extend than previous learning environments provides various learning support.

The specialists M. De Wit and H. Van Dompseler (2017) from the university in Utrecht (Netherlands) distinguish and describe in details the functional components of modern digital environment for tertiary institutions:

1. Organisation of Learning or Learning Management - clear and easy access to the content and annexes.

2. Digital Testing, aimed at improving the quality of testing and learning in general.

3. Submission and Assessment of Assignments - function that provide the qualitative coordination and feedback with students, including the check of student works for plagiarism.

4. Management and Use of Student Information - managing students' administrative data (including personal data), registration of lesson attendance, assessment etc.

5. Timetabling.

6. Internships and Final Projects - interaction between a student and an organisation where the internship takes place; managing contracts and documents, monitoring of the internship quality.

7. Developing, Managing and Sharing Learning Materials. 
8. Education Process Support - developing tools that are used for monitoring students' attainment and providing them with target feedback for education process support.

9. Learning Analytics.

10. Communication.

11. Collaboration.

12. Multimedia.

13. Freely Available Applications (Wit \& Dompseler, 2017).

The analysis of available experience of developing and working with modern digital (electronic) learning environments, developed for different education stages, proves that foreign science and practice outpace the national ones, which only starts working in this direction. The outpacing concerns hi-tech software of foreign open education and Next Generation of Digital Learning Environment, as well as acceptance of e-education at the legislative level (with getting diplomas, certificates and licenses).

Digital learning environment for primary school teacher training at SHEI "Donbas State Pedagogical University" is developed, taking into consideration the study of national and foreign experience, as well as the real capacities of lecturers of the tertiary institution who are knowledgeable in modern information scientific and pedagogical content without any special computer education and have a welldeveloped digital competence.

Thus, the following components are distinguished in the structure of learning environment for primary school teacher training: digital learning resources, webconferences, scientific and methodological repository, methodological portal, distance courses for school leavers, forums, and news. We will consider in details the content of every subsection of the learning environment, having been modelled:

1. In the subsection "Digital Learning Resources", the location of electronic learning tools of primary school teacher professional training is planned. They are:

- electronic textbooks for the courses of Bachelor students professional training, such as "Children Literature with Teaching Methodology" (I. Khyzhniak, V. Syrotenko), "Methodology of Teaching the Subject "I Explore the World", "Introduction to Specialty" (I. Viktorenko).

- electronic teaching aids for learning and methodological support of courses, taught for Master students of specialty 013 Primary education, namely "History of Ukrainian Music", "History of Ukrainian Culture"; learning and methodological tutorial "Ukrainian Spiritual Music" (L. Havrilova), "Ukrainian Culture of the End of the $19^{\text {th }}$ - beginning of $20^{\text {th }}$ century" (L. Havrilova, N. Voronova); 
- electronic textbook "Information and Communication Technologies in Pedagogical Research" (L. Havrilova) for students of the third stage of educational and scientific level of higher education (PhD students of specialty 013 Primary education and 015 Vocational Education).

Digital learning resources, planned to be included into the digital learning environment of primary school teacher training, are developed according to the requirements of "Regulation on Electronic Textbooks", so they are made on the basis of curriculum of the certain course; they contribute to the completeness of expanding main scientific regulations, the use of generally accepted scientific conceptualization, relevant facts and data; they take into consideration the principles of competency-based approach, contain the tasks for self-assessment, group work, open questions, research, cognitive and creative activities, activities for independent work (Regulations, 2018). The authors of electronic learning tools pay attention to the interface and design of etextbooks, the technical and functional requirements (existing navigation tools according to the structural items, including subject index, name index, interactive elements, multimedia content).

2. Internet-conferences. The separate subsection of digital learning environment of primary school teacher training contributes to effective scientific communication by means of special software. Taking into account the fact that the Department of Primary Education Theory and Practice holds international Internetconferences, we have decided to hold them in the learning environment, having been modelled.

As it is known, holding web-conferences is designed and both free and commercial software is successfully used. They are famous services Apache OpenMeetings, Adobe Connect Pro Meeting, Microsoft Teams (center for command work in Office 365 from Microsoft), Microsoft Lync and others, which ensure holding audio and video conferences, support additional functions, including the exchange of messages, files, streaming audio and video, collaborative editing of documents, creating the recording of the event, collaborative planning of doing the activities, and conducting the voting and questionnaire.

In the conditions of digital learning environment, the Internet-conference "Professionalism of the Teacher in the Conditions of Educational Innovations" (2018) was held, so the software with open code BigBlueButton was used which made it possible to communicate with colleagues-scientists and specialists in the sphere of primary education and digital technologies from National Pedagogical Dragomanov University (Kyiv, Ukraine) and Jan Kochanowski University of Humanities and Sciences (Kielce, Poland). 
3. The subsection "Webinars" in the structure of modelled digital learning environment is planned to be used for giving educational online services: conducting online trainings on the relevant issues ("Competences of New Ukrainian School", "Algorithm of Writing Scientific Papers", "International Scientometric Database" etc.). MyOwnConference, Google Hangouts, Facebook live, Skype Group Calls are free platforms for holding webinars that are accessible to everyone and easy to use.

4. Scientific and methodological repository in digital learning environment of primary school teachers training - is in fact electronic library where scientific and methodological products of lecturers of the Department of Primary Education Theory and Practice are stored:

- scientific articles, grouped according to the significance of the editions (articles, indexed in scientometric database Scopus and Web of Science; articles, indexed in Index Copernicus; articles, published in professional journals of Ukraine; proceedings of International and Ukrainian conferences);

- methodological conferences for seminars on professional courses of primary school teacher training;

- methodological tips for students' independent work;

- electronic versions of paper textbooks and learning-methodological tutorials, namely: Electronic Linguomethodology in Tertiaty Institutions, a textbook for Master students (I. Khyzhniak); Electronic Linguomethodology Tools, a tutorial for Bachelor students (I. Khyzhniak); Information and Communication Technologies in Pedagogical Research, learning-methodological tutorial for students of pedagogical tertiary institutions (L. Havrilova, K. Kukhar, Ya. Topolnyk);

- tasks for conducting ongoing and final control;

- methodological recommendations for organisation and conducting of future teachers' internship.

5. Methodological portal in digital learning environment of primary school teachers training was developed for supporting the effective collaboration with primary school teachers. The lesson plans of primary school subjects are intended to be located in this subsection. Here the review of teachers' papers is planned to be conducted with further publication of the best articles in electronic scientific journal "Professionalism of the Teacher: Theoretical and Methodological Aspects" (http://pptma.dn.ua/).

6. Subsections "Forum" and "News" ensure communication, contribute to educational interaction between lecturers and students, the exchange of ideas between lecturers, the organisation of scientific and methodological discussions, as well as they inform about the changes in educational process, timetable, exam schedule etc.

The conclusions and the perspectives of further research. The analysis of 
national and foreign experience of developing open electronic learning environment makes it possible to understand the main approaches to designing and realizing digital learning environment, which must meet the principles of open education, concentrate all the necessary components in one place and implement different functions that include submitting materials, testing, managing data, timetabling, learning analytics, multimedia, tools for collaboration and communication, tools for exchanging materials and supporting the learning process. An important task of modern learning platform is to support the learning activities of lecturers and students. The example of universal digital learning platform for school teachers and students, lecturers and students, location and providing software, educational services and tools for managing the education is the Next Generation of Digital Learning Environment (NGDLE) that is a new generation of learning resources with modern software.

Digital learning environment of primary school teacher training, designed by the lecturers of the Department of Primary Education theory and Practice at SHEI "Donbas State Pedagogical University", was developed, taking into consideration both national and foreign experience. The learning resource meets the principles of open education and consists of the following subsections: digital learning resources, web-conferences, webinars, scientific and methodological repository, methodological portal, distance courses for school leavers, forum, and news.

The prospects of further research are connected with the practical implementation of digital learning environment of primary school teacher training and the check of its effectiveness.

\section{REFERENCES}

1. ACCENT Universal Education Space. (n.d.). Retrieved from http://ac-cent.com/.

2. Brown, M. (2017). The NGDLE: We Are the Architects. EDUCAUSE Review, $11-18$. Retrieved from https://er.educause.edu/-/media/files/articles/2017/7/erm17411.pdf.

3. Dobbin, G. (2016). Exploring the Next Generation Digital Learning Environment: Opportunities and Challenges.

Retrieved from https://library.educause.edu/resources/2016/6/exploring-the-next-generation-digital-learningenvironment-opportunities-and-challenges

4. Electronic Educational Resources Regulations. № 1060. (2012, 1 October). Retrieved from http://zakon2.rada.gov.ua/laws/show/z1695-12\#n13.

5. Inamorato dos Santos, A., Punie, Y., Castaño-Muñoz, J. (2016). Opening up Education: a Support Framework for Higher Education Institutions. JRC Science for Policy Report, EUR27938EN; DOI:10.279.1/293408.

6. Kartashova, L. A., Bakhmat, N. V., \& Plish, I. V. (2018). Development of the digital competence of the teacher in the information and educational environment of the institution of general secondary education. Informatsiini tekhnolohiyi i zasoby navchanniya, 68 (6), 193-205.

7. Liubarets, V. (2016). Creating an ACCENT online education platform is the path to quality education. Vyshcha osvita Ukrainy, 3, 58-63. Retrieved from http://nbuv.gov.ua/UJRN/vou_2016_3_10. 
8. Lynch, M. (2018). What is the Next Generation of Digital Learning Environments? Retrieved from_https://www.thetechedvocate.org/what-is-the-next-generation-of-digital-learningenvironments/.

9. Regulations about electronic tutorial. № 440. (2018, 2 May). Retrieved from https://zakon.rada.gov.ua/laws/show/z0621-18

10. Regulations on the National Educational Electronic Platform. №523. (2018, 22 May). Retrieved from https://zakon2.rada.gov.ua/laws/show/z0702-18.

11. Strategy of Information Society Development in Ukraine. № 386-p. (2013, 15 May). Retrieved from http://zakon4.rada.gov.ua/laws/show/386-2013-p.

12. The New Ukrainian School: Conceptual Foundations for General School Reform. Retrieved from http://nus.org.ua/wp-content/uploads/2017/07/konczepcziya.pdf.

13. Ukraine's Digital Agenda $\quad-\quad 2020 . \quad$ Retrieved from https://ucci.org.ua/uploads/files/58e78ee3c3922.pdf.

14. Wit, M., \& Dompseler, H. (2017). How to create a digital learning environment consisting of various components and acting as a whole? Retrieved from http://www.eunis.org/download/2017/EUNIS_2017_paper_16.pdf.

15. A Digital Agenda for Europe / Communication from the Commission to the European Parliament, the Council, the European Economic and Social Committee and the Committee of the Regions. Brussels, 19.5.2010. 245 final. Retrieved from http://eur-lex.europa.eu/legalcontent/EN/TXT/PDF/?uri=CELEX:52010DC0245R(01)\&from=EN

\title{
ЦИФРОВИЙ ОСВІТНІЙ ПРОСТІР ПІДГОТОВКИ УЧИТЕЛІВ ПОЧАТКОВОЇ ШКОЛИ
}

\author{
Людмила Гаврілова \\ доктор педагогічних наук, професор, \\ завідувач кафедри теорії і практики початкової освіти, \\ ДВНЗ «Донбаський державний педагогічний університет» \\ м. Слов’янськ Донецької області, Україна \\ ORCID ID 0000-0003-1814-5323 \\ havrilovalg@gmail.com

\section{Олена Бескорса} \\ кандидат педагогічних наук \\ доцент кафедри теорії і практики початкової освіти \\ ДВНЗ «Донбаський державний педагогічний університет», \\ м. Слов’янськ Донецької області, Україна \\ ORCID ID 0000-0001-8018-8549 \\ beskorsyhelen@gmail.com
}

Анотація. Питання створення цифрового освітнього середовища, яке б відкривало доступ сучасних освітніх ресурсів та забезпечило новий рівень взаємодії викладачів з учнями, $\epsilon$ надзвичайно актуальним для вітчизняної системи вищої освіти. Розвиток цифрових технологій дозволяє створити якісне, високотехнологічне освітнє середовище для підготовки фахівців різних спеціальностей. Підписання України Угоди про Асоціацію з СС прискорило процеси цифровізації вітчизняної освіти, що доводить низка законодавчих ініціатив та 
стратегічних документів, серед яких Цифрова адженда України - 2020 (2016), Закон України Про освіту (2017) та Концепція Нової української школи (2017), Положення про електронний підручник (2018), Положення про Національну освітню електронну платформу (2018).

Метою статті $\epsilon$ аналіз та узагальнення вітчизняного й зарубіжного досвіду щодо створення відкритого електронного освітнього середовища, що дозволило змоделювати цифровий освітній простір підготовки учителів початкової школи, опис структури і змісту цього педагогічного явища. Теоретичне підгрунтя дослідження складають принципи відкритої освіти та положення компетентнісного підходу. Автором проаналізовано вітчизняний досвід створення інноваційного е-середовища: розглянуто модель електронної освітньої платформи - Універсальний освітній простір ACCENT (http://ac-cent.com/), електронна платформа mobiSchool, розроблені українськими науковцями та реалізованими на практиці як вебінструментарій електронного навчання в закладах середньої освіти.

Засвідчено значно більший досвід створення електронних освітніх ресурсів, у тому числі відкритих цифрових навчальних засобів, курсів, підручників у країнах зарубіжжя. Серед поширених інформаційно-комунікаційних середовищ відкритої освіти названо Ореn Educational Resources (OER, https://www.oercommons.org/), Coursera (http://www.coursera.org), Academic Earth (http://academicearth.org), онлайн-платформи репозитаріїв освітніх ресурсів Гарвардського, Пристонського університетів, Массачусетського технологічного інституту та ін.

Зазначено, що в зарубіжній педагогіці наразі йдеться про більш сучасне покоління освітніх ресурсів, Next Generation of Digital Learning Environment (NGDLE). NGDLE розробляється як універсальна цифрова навчальна платформа для вчителів та учнів, викладачів та студентів, місце розташування й надання програм, послуг навчання та інструментів управління навчанням. Автором описано проект цифрового освітнього простору підготовки учителів початкової школи, розроблений викладачами ДВНЗ “Донбаський державний педагогічний університет”. Освітній ресурс відповідає принципам відкритої освіти й складається із наступних підрозділів: цифрові освітні ресурси, веб-конференції, вебінари, науково-методичний репозитарій, методичний портал, дистанційні курси для абітурієнтів, форум та новини. У перспективі дослідження - практична реалізація цифрового освітнього простору підготовки учителів початкової школи та перевірка його ефективності.

Ключові слова: цифровий освітній простір; відкритий доступ; відкриті освітні ресурси; середовище е-навчання; Національна освітня електронна платформа; вчителі початкової школи.

\section{СПИСОК ВИКОРИСТАНИХ ДЖЕРЕЛ}

1. Brown, M. (2017). The NGDLE: We Are the Architects. EDUCAUSE Review, $11-18$. Retrieved from https://er.educause.edu/-/media/files/articles/2017/7/erm17411.pdf.

2. Dobbin, G. (2016). Exploring the Next Generation Digital Learning Environment: Opportunities and Challenges. Retrieved from https://library.educause.edu/resources/2016/6/exploring-the-next-generation-digital-learningenvironment-opportunities-and-challenges

3. Inamorato dos Santos, A., Punie, Y., Castaño-Muñoz, J. (2016). Opening up Education: a Support Framework for Higher Education Institutions. JRC Science for Policy Report, EUR27938EN; DOI:10.279.1/293408.

4. Lynch, M. (2018). What is the Next Generation of Digital Learning Environments? Retrieved from_https://www.thetechedvocate.org/what-is-the-next-generation-of-digital-learningenvironments/.

5. Wit, M., \& Dompseler, H. (2017). How to create a digital learning environment consisting of various components and acting as a whole? Retrieved from http://www.eunis.org/download/2017/EUNIS_2017_paper_16.pdf. 
6. A Digital Agenda for Europe / Communication from the Commission to the European Parliament, the Council, the European Economic and Social Committee and the Committee of the Regions. Brussels, 19.5.2010. 245 final. Available from http://eur-lex.europa.eu/legalcontent/EN/TXT/PDF/?uri=CELEX:52010DC0245R(01)\&from=EN

7. Карташова, Л. А., Бахмат, Н. В., Пліш, I. В. (2018). Розвиток цифрової компетентності педагога в інформаційно-освітньому середовищі закладу загальної середньої освіти. Інформачійні технології і засоби навчання, 68 (6), 193 - 205.

8. Любарець, В. (2016). Створення електронної освітньої платформи ACCENT - шлях до якісної освіти. Вища освіта Украӥни, 3, 58 - 63 . Взято 3 http://nbuv.gov.ua/UJRN/vou_2016_3_10.

9. Нова українська школа: концептуальні засади реформування загальної школи. Взято 3 http://nus.org.ua/wp-content/uploads/2017/07/konczepcziya.pdf.

10. Положення про електронний підручник. № 440. (2018, 2 травня). Взято 3 https://zakon.rada.gov.ua/laws/show/z0621-18

11. Положення про електронні освітні ресурси. № 1060. (2012, 1 жовтня). Взято 3 http://zakon2.rada.gov.ua/laws/show/z1695-12\#n13.

12. Положення про Національну освітню електронну платформу. № 523. (2018, 22 травня). Взято з https://zakon2.rada.gov.ua/laws/show/z0702-18.

13. Стратегія розвитку інформаційного суспільства в Україні. № 386-р. (2013, 15 Травня).Взято 3 http://zakon4.rada.gov.ua/laws/show/386-2013-p.

14. Універсальний освітній простір ACCENT : офіційний веб-портал. Взято з http://accent.com/.
15. Цифрова
адженда
України
2020.
Взято
3 https://ucci.org.ua/uploads/files/58e78ee3c3922.pdf.

Матеріали надійшли до редакції 05.08.2019 р. 